\title{
Kitap İncelemesi
}

\author{
YAZARLAR : Ayşen Cem Değer, Betül Çetin, Emine Oflaz Köleci \\ BAŞLIK \\ YAYINEVI \\ : Kuramdan Uygulamaya Yabancılara Türkçe Dilbilgisi Öğretimi \\ BASIM YILI \\ : Pegem Akademi \\ SAYFA SAYISI \\ : 2018 (4. Bask1) \\ INCELEYEN \\ $: 154$ \\ : Funda Uzdu Yildız
}

\section{Özet}

Yabancı dil olarak Türkçe öğretiminde öğreticilerin yararlanabileceği kaynakların sayısı her geçen gün hem nicelik hem de nitelik açısından artmaktadır. Dilbilgisi öğretimi konusunda özellikle öğretmenlere kaynaklık etmeyi amaçlayan bir kitap olan Kuramdan Uygulamaya Yabancılara Türkçe Dilbilgisi Öğretimi, dilbilgisi konularının öğretiminde izlenebilecek yolları uygulama örnekleriyle birlikte sunan bir çalışmadır. Kitabın önsözünde belirtilen bazı açıklamalar okuyucular için kitabın hedef kitlesini ve amacını açıkça ortaya koymaktadır. Kitap, farklı lisans alanlarında eğitimlerini tamamlamış yabancı dil olarak Türkçe öğretmenleri kitlesine hitap etmektedir. Yazarlar Türkçenin dilbilgisi konularının yabancılara öğretimi için sunum ve uygulama örneklerini biçim/anlam/kullanım bakış açısıyla ele almış bağlam içinde öğretim etkinlikleriyle açıklamışlardır.

Adında da yer verildiği üzere "kuramdan uygulamaya dilbilgisi öğretimi” üzerine bilgilerin etkinlik örnekleriyle birlikte yer aldığı kitap dört temel bölümden oluşmaktadır.

\section{Değerlendirme}

Kitabın önsözünde kitabın kimler için ve ne amaçla yazıldığını açık bir şekilde belirtilmektedir. Bu bilgiler okuyuculara kitap hakkında bilgi vermesi bakımından oldukça yararlıdır. Günümüz okuyucusu kaynak kitapları incelemeye başladığında bu gibi bilgileri bir okuma çerçevesi olarak değerlendirmekte ve çalışmayı benzer diğer çalışmalar içinde değerlendirirken ayırıcı özelliklerini görebilmektedir. Yine önsözde yazarların dilbilgisi öğretimine bakış açılarını belirtmeleri, içerikte yer alan bilgilerin yorumlanabilmesi ve etkinliklerin anlaşılabilmesi açısından açıklayıcı olmuştur. Okuyucular için bilgilerin yer aldığı bu bölümde yazarlar hakkında bilgiler de verilmiştir.

Birinci bölümde dil öğretiminde dilbilgisi konusuna alan yazınındaki ilgili ve çağdaş kaynaklardan alınan bilgiler ile bakış açıları çerçevesinde değinilmektedir. Öğretimde biçim/anlam ve kullanım üçlüsünü açıklayan bu bölümde dilbilgisi öğrenimine öğrenme süreçleri (bilişsel, duyuşsal ve sosyal) açısından da yer verilmiştir. $\mathrm{Bu}$ başlıklandırma değerlendirildiğinde öğretmenlerin dilbilgisi öğretiminde yalnızca öğretime odaklanmalarının yeterli olmadığı; öğrenme süreçlerini bilerek bu süreçlere göre öğretimi 
planlamaları gerektiği yorumu yapılabilmektedir. Yazarlar bu konudaki görüşlerini ve kitabın bölümleri arasındaki ilişkiyi aşağıdaki şekilde sunmuşlardır:

Biz, bu kitapta dilbilgisinin bağlamdan bağımsız olarak ele alınamayacağını vurguluyor ve Türkçenin herhangi bir yapısal özelliğinin bağlam içinde 'biçim', 'anlam' ve 'kullanım' ile birlikte öğreniciye sunulduğunda ve buna yönelik tekrar ve alıştırmalarla pekiştirildiğinde akılda kalıcı olacağını ve öğrenicinin sözü edilen yapıyı Türkçeyi yazarken ve konuşurken daha kolay kullanabileceğini savunuyoruz. Bu nedenle kitapta I. Bölümde Türkçenin kimi dilbilgisi özelliklerini biçim, anlam ve kullanım üçlüsü içinde tartışıyoruz. Bu bölümde tartıştığımız dilbilgisi birimleri kitabın diğer bölümlerinde 'Sunum' ve 'Uygulama' örnekleri olarak da yer alıyor. Böylece, bağlam içinde biçimi, anlamı ve kullanımıyla bütüncül olarak ele aldığımız bir dilbilgisi birimini I. Bölümde betimlerken II., III. ve IV. Bölümlerde önerdiğimiz Sunum ve Uygulama önerilerini bu betimlemeleri temel alarak yapiyoruz.

İkinci bölümde "kuraldan yola çıkarak dilbilgisi öğretmek başlığı" altında kuralların nasıl anlatılması gerektiği, öğretmenin kuralı sunuşu, bilgi boşluğu bırakılarak kuralın sunumu, kurala bakarak yanlışı bulma alt başlıkları yer almaktadır.

Üçüncü bölüm örneklerden yola çıkarak dilbilgisi öğretimi konusunu aktarmaktadır. Örneklerin hangi tekniklerle sunulacağına bağlı olarak içerik oluşturulmuş ve beş teknik detaylı olarak anlatılmıştır. Bu teknikler karşılaştırma, sıralama, boşluk doldurma, dönüştürme ve yeniden oluşturmadır. Karş1laştırma bölümünde metin aracılığıyla karşılaştırma, çıktı aracılığıyla karşılaştırma ve sına-öğret-sına teknikleri örnek anlatımlarla birlikte açıklanmıştır.

Dördüncü bölüm olan uygulama bölümünde etkinlik örneklerine geçilmeden önce biçime odaklanan etkinlikler, iletişimsel etkinlikler, uygulama aşamasında öğrencinin katılımını sağlamak, biçimden kullanıma doğru başlıkları altında etkinliklerin gereksinimlere göre düzenleniş biçimleri ve uygulanışları hakkında bilgiler verilmiştir. Uygulama bölümünün beşinci bölümünde örnekler yer almaktadır. $\mathrm{Bu}$ bölüm öğretmenlerin dilbilgisi öğretimi derslerinde yararlanabilecekleri uygulanmış, denenmiş sınıf içi uygulama örneklerini içermektedir. Şu başlıklar altında örneklere yer verilmiştir: kontrollü zincir etkinlikleri, altını çizme/bulma/işaretleme, boşluk doldurma, denetlemeli yazma, yanlışı düzeltme, seçme, tümce yazma/tamamlama, eşleştirme/birleştirme, yeniden yazma, yönlendirmeli yazma, yapı temelli özgür tümce üretme, yapı/işlev temelli söylem üretme, bilgi boşluğu etkinlikleri ve drama etkinlikleri olarak on dört etkinlik uygulamas1 farklı düzeylerde yer alan dilbilgisi konularıyla birlikte uygulama biçimlerini sunmaktadır. Yabancı dil olarak Türkçe öğretimi alanında kuramsal bilgi veren kaynakların bazılarında yer alan öneriler yalnızca yazarların tahminleriyle oluşturduğu örnekleri içermektedir. Bu durum, öğreticilerin bu gibi kaynaklardan yararlanarak hazırlayacakları etkinlikleri uygulanabilir olma konusunda sıkıntıya sokabilmektedir. Bu kitapta özellikle denenmiş, uygulanmış etkinliklerin örnek olarak sunulması kitabın kullanıcılar açısından daha güvenilir ve yararlanılabilir olmasını sağlayabilir.

Kitap toplamda 33 çalışma kâğıdı içermektedir. Bu çalışma kâğıtlarındaki uygulamaların başka dilbilgisi konularına aktarılabilir olması kullanıcılar açısından oldukça işlevsel kullanılabilmesini sağlamaktadır. Ayrıca yazarların da belirttiği gibi dilbilgisi konularının bağlam içindeki çeşitlenmelerini sunan bu çalışma kâğıtları iletişimsel edincin gelişmesine katkı da sunabilir.

Kitap boyunca da vurgulayacağımız gibi, Türkçenin dilbilgisi öğretimine yaklaşımımız yalnızca Türkçenin biçimsel özellikleri üzerine odaklanmak değil, biçimsel özellikleri göz ardı 
etmeden, Türkçe dilbilgisinin bir bağlam içinde kullanımındaki çeşitlenmeleri için de öğretim teknikleri sunmaktır. $\mathrm{Bu}$ şekilde, öğrenicilerin iletişimsel edincinin gelişmesine katkıda bulunabilmeyi umuyoruz.

Bir lisans programı olmayan yabancı dil olarak Türkçe öğretimi alanında kendini yetiştirmek isteyen uygulayıcıların ve bu alanda lisansüstü düzeyde çalışma ve araştırma yapanların yararlanabilecekleri, akademik anlamda güncel bilgiler içeren ve uygulayıcılara somut, anlaşılır, uyarlanabilir örnekler sunan kitap 2018 yılında dördüncü baskısını yapmıştır. Bir yıl içinde dördüncü baskıya ulaşmış olması yabancı dil olarak Türkçe alanında akademik anlamda ya da uygulayıcı olarak çalışanların bu gibi kaynaklara gereksinim duyduğunu göstermektedir.

\section{İnceleyen Hakkında Bilgi}

Funda Uzdu Yıldız, Dokuz Eylül Üniversitesi Edebiyat Fakültesi Dilbilim Bölümünde Dr. Öğretim Üyesi olarak çalışmakta olup Dokuz Eylül Üniversitesi Eğitim Bilimleri Enstitüsü Yabancı Dil olarak Türkçe Öğretimi Yüksek Lisans programında YTÖ’de Dilbilgisi Öğretimi, YTÖ’de Materyal Hazırlama ve Geliştirme derslerini; Sosyal Bilimler Enstitüsü Genel Dilbilim Yüksek Lisans Programında Yabancı Dil olarak Türkçe derslerini yürütmektedir. Dokuz Eylül Üniversitesi Dil Eğitimi Uygulama ve Araştırma Merkezinde müdür yardımcısı olarak çalışmaktadır. Çalışmalarını yabancı dil olarak Türkçe öğretimi alanında sürdürmektedir. funda.uzdu@deu.edu.tr 